\section{Measurement of quantity of iron in magnetically labeled cells: comparison among different UV/VIS spectrometric methods}

\author{
Ali M. Rad ${ }^{1}$, Branislava Janic ${ }^{1}$, ASM Iskander ${ }^{1}$, Hamid Soltanian-Zadeh ${ }^{1,2}$ \\ and Ali S. Arbab ${ }^{1}$ \\ 'Henry Ford Hospital, Detroit, MI, USA and 'University of Tehran, Tehran, Iran
}

BioTechniques 43:627-636 (November 2007)

doi 10.2144/000112599

Cell labeling with superparamagnetic iron oxides (SPIO) is becoming a routine procedure in cellular magnetic resonance imaging (MRI). Quantifying the intracellular iron in labeled cells is a prerequisite for determining the number of accumulated cells by quantitative MRI studies. To establish the most sensitive and reproducible method for measuring iron concentration in magnetically labeled cells, we investigated and compared four different methods using an ultraviolet-visible (UV/VIS) spectrophotometer. Background spectra were obtained for 5 and $10 \mathrm{M}$ hydrochloric acids, a mixture of $100 \mathrm{mM}$ citric acid plus ascorbic acid and bathophenanthroline sulphonate (BPS), and a mixture of $5 \mathrm{M}$ hydrochloric acid plus 5\% ferrocyanide. Spectra of the same solutions containing either 10 or $5 \mu \mathrm{g} / \mathrm{mL}$ iron oxides were also created to determine the peak absorbance wavelengths for the dissolved iron. In addition, different known iron concentrations were used to obtain calibration lines for each method. Based on the calibration factors, iron was measured in samples with a known amount of iron and in labeled cells. Methods based on the use of $10 \mathrm{M}$ hydrochloric acid underestimated iron concentration in all experiments; for this method to give an accurate measurement, iron concentration in sample needs to be at least $3 \mu \mathrm{g} / \mathrm{mL}$.

\section{INTRODUCTION}

Cellular magnetic resonance imaging (MRI) techniques enable in vivo imaging and tracking of in vivoadministered magnetically labeled cells. Labeling of cells with ferumoxides or other superparamagnetic iron oxides (SPIO) or ultra-small SPIO (USPIO) is therefore an important step and is becoming a routine procedure in cellular MRI (1-7). Accurate MRI quantification of in vivo-accumulated labeled cells requires a reliable and sensitive method for determining the concentration of intracellular iron in labeled cells before their in vivo administration. Quantitative analysis of intracellular iron concentration can be accomplished using a variety of analytical methods. Still, one of the most important factors that needs to be considered when quantifying intracellular iron concentration is the sensitivity of the method and its ability to determine the low concentrations of iron.
Available commercial kits for determining iron concentration in various types of solutions (e.g., QuantiChrom Iron Assay kit; BioAssay Systems, Hayward, CA, USA) are not sensitive enough for measuring low iron concentrations that are usually used for labeling cells with the USPIO nanoparticles. Nuclear magnetic resonance (NMR) relaxometric methods can also be employed to measure the concentration of iron, and these are based on the linear relationship between iron content and NMR relaxation rates 1/T1 or 1/T2 (8). By using either custom designed equipment or commercially available MRI scanners, T1 and T2 relaxation rates obtained from samples are compared with the known iron concentration in serial dilutions of iron solution that is used for generating standard calibration curve. However, the MRI method is rather cumbersome, and MRI equipment is not readily available for routine use in many cell biology laboratories. Inductively coupled plasma mass spectrometry
(ICP-MS) and optical emission spectroscopy (OES) are rapid, sensitive analytical tools that have also been used to determine iron concentration in cells $(9,10)$. Most of the described techniques can be performed in standard laboratory settings; however ICP-MS is not available in all laboratories that are involved in magnetic labeling of cells, and the samples for ICP-MS are usually sent out to core facility or analytical laboratory for analysis. Various groups have utilized different methods to determine iron concentration in biological samples, and while ICP-MS may be considered as a more accurate method, so far none of the methods has been identified as gold standard for measuring intracellular iron concentration. Moreover, sensitivity of method in determining nanogram levels of iron is another important factor to be considered when choosing the appropriate method.

Among various methods that are available for determining the concentration of iron in labeled cells (11-14), the most commonly used are spectrophotometric methods that rely on acid digestion of cells followed by the Ferrozine-based assay for iron. Ferrozine is an iron-chelating agent that forms a complex with ferrous iron $\left(\mathrm{Fe}^{2+}\right)$ and exhibits characteristic UV/ VIS absorption at $562 \mathrm{~nm}$. However, many investigators who have used spectrophotometric methods differ in regard to the chemical composition as well as the wavelength to be used in the assay $(6,15)$. In addition, methods using different concentrations of hydrochloric acid alone or in combination with potassium ferrocyanide have been reported (15). Moreover, there has been no consensus among the investigators on the absorbance wavelength even when only hydrochloric acid was used $(15,16)$. Previously, our group has also reported various methods for determining iron concentration in labeled cells such as MRI imaging relaxometrybased method and Ferrozine-based spectrophotometric assay $(6-8,14)$.

To establish the most sensitive and reproducible method for determining dissolved iron concentration, we investigated and compared four distinct UV/VIS spectrophotometric methods. This was achieved by determining the 
following three parameters: (i) peak absorbance values for solutions alone that are used in each method; (ii) peak absorbance values for iron dissolved in the solution specific for each method; and (iii) separate calibration line calculation for each method, based on the peak absorbance values of iron dissolved in specific solution for the given method. Finally, to confirm the accuracy and validity of methods, we measured the concentration of iron in the samples of known iron concentration and separately tested the recovery of iron by each method.

\section{MATERIALS AND METHODS}

\section{Chemicals and Laboratory Wares}

The following chemicals and laboratory wares were used: $37 \%$ hydrochloric acid, citric acid, sodium citrate, potassium ferrocyanide (Fisher Biosciences, Rockford, IL, USA), 99\% sodium ascorbate (Acros Organics, Morris Plains, NJ, USA), bathophenanthroline sulphonate (BPS; Sigma-Aldrich, St. Louis, MO, USA), ferumoxides (Feridex; Berlex Laboratories, Montville, NJ, USA), protamine sulfate (American Pharmaceuticals Partners, Shaumburg, IL, USA), Millipore-Q purified water (Millipore, Billerica, MA, USA), phosphate-buffered saline (PBS; MediaTech, Herndon, VA, USA), 1.5-mL microcuvettes (Bio-Rad Laboratories, Hercules, CA, USA), $1.5-\mathrm{mL}$ microcentrifuge polypropylene tubes, $15-\mathrm{mL}$ polypropylene centrifuge tubes (Corning-Costar, Lowell, MA, USA), and THP-1 monocyte tumor cells (ATCC, Manassas, VA, USA).

\section{Spectrometric Profile of Different Reagent Mixtures With or Without Iron}

For hydrochloric acid at the concentrations of 10 and $5 \mathrm{M}$, a mixture of $100 \mathrm{mM}$ citric acid, $\mathrm{pH} 2.0$, plus 100 $\mathrm{mM}$ ascorbic acid and $5 \mathrm{mM}$ BPS and a mixture of $5 \mathrm{M}$ hydrochloric acid plus $5 \%$ ferrocyanide $(\mathrm{w} / \mathrm{v})$ were prepared, and spectra were obtained by a UV spectrophotometer (UVmini-1240;
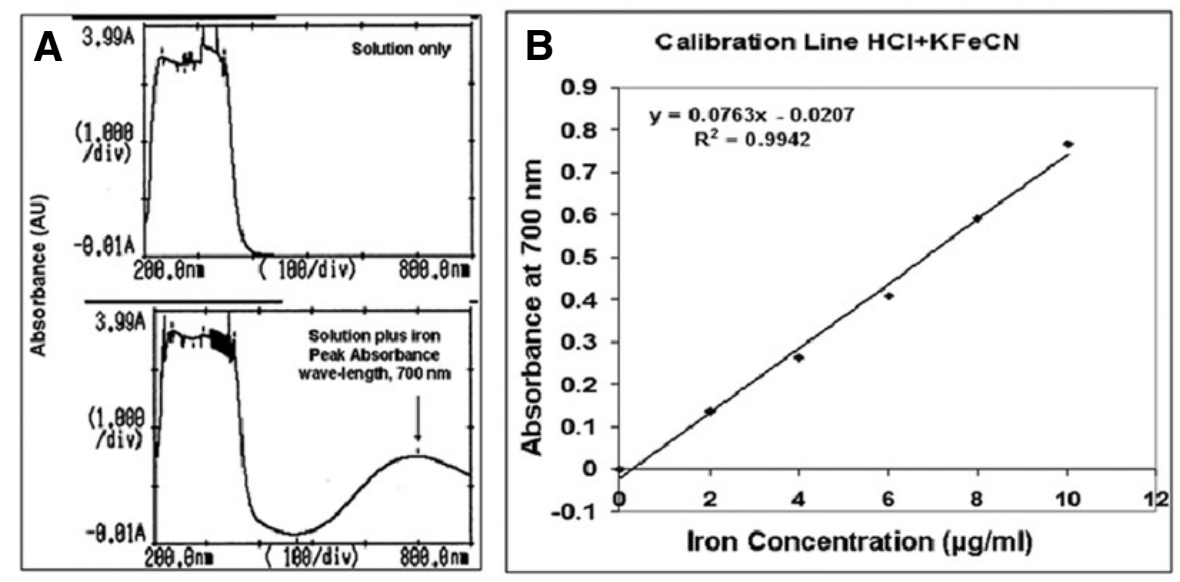

Figure 1. Peak absorbance values and calibration line for hydrochloric acid plus ferrocyanide method. (A) Peak absorbance values for hydrochloric acid plus ferrocyanide without iron (top panel) and with $5 \mu \mathrm{g}$ iron (bottom panel). (B) The calibration line for hydrochloric acid plus ferrocyanide method generated by using iron in concentration ranging from 0 to $10 \mu \mathrm{g} / \mathrm{mL}$.

Shimadzu, Tokyo, Japan) to determine the background peak absorbance (Abs) wavelength of the solutions. Spectra of all the above solutions containing either 10 or $5 \mu \mathrm{g} / \mathrm{mL}$ ferumoxides (for hydrochloric acid only or other reagent mixtures, respectively) were also obtained to determine the peak absorbance wavelengths for dissolved iron using the same spectrophotometer. Ferumoxide is composed of small iron core that is made of multicrystal $\mathrm{Fe}$ (II) and $\mathrm{Fe}$ (III) iron oxides (4-5 $\mathrm{nm})$ and incomplete dextran coating. The following methods were used to determine the spectrometric profiles of dissolved iron.

(i) Potassium ferrocyanide and hydrochloric acid (method A). Ferumoxide solution containing $5 \mu \mathrm{g}$ iron (diluted in PBS) was incubated at $110^{\circ} \mathrm{C}$ overnight (no cap on tubes). After evaporation of the liquid, $1 \mathrm{~mL}$ hydrochloric acid (5 M) was added, and samples further incubated at $60^{\circ} \mathrm{C}$ for 4 $\mathrm{h}$. Tubes were capped to prevent evaporation of the acid. After the incubation, $0.5 \mathrm{~mL}$ solution from each tube was transferred to a separate $1.5-\mathrm{mL}$ cuvette, and $0.5 \mathrm{~mL}$ freshly prepared $5 \%$ potassium ferrocyanide was added to each cuvette and incubated at room temperature in dark for $35 \mathrm{~min}$. Prussian blue color developed in the reaction of the mixtures and became stable after $35 \mathrm{~min}$. After $35 \mathrm{~min}$, the absorbance was measured. Absorption profile of 200- to $800-\mathrm{nm}$ wavelengths was plotted to determine the peak absorbance wavelength. The peak absorbance for solution containing iron was $700 \mathrm{~nm}$.

(ii) Hydrochloric acid, 10 M (method B). In this method, ferumoxide solution containing $10 \mu \mathrm{g}$ iron (diluted in PBS) was incubated at $110^{\circ} \mathrm{C}$ overnight (no cap on tubes). After evaporation of the liquid, $1 \mathrm{~mL}$ hydrochloric acid $(10 \mathrm{M})$ was added, and samples further incubated at $60^{\circ} \mathrm{C}$ for $4 \mathrm{~h}$. Tubes were capped to prevent the acid evaporation. Then $0.5 \mathrm{~mL}$ solution from each tube was transferred to a separate $1.5-\mathrm{mL}$ cuvette, and $0.5 \mathrm{~mL} 10 \mathrm{M}$ hydrochloric acid was added to each cuvette after which the absorbance was measured. Absorption profile of 200- to $800-\mathrm{nm}$ wavelengths was plotted to determine the peak absorbance wavelength. The peak absorbance for solution containing iron was $351 \mathrm{~nm}$. It is not exactly clear what products made this colorimetric complex, but it is possible that $\mathrm{FeCl}_{3}$, one of the reaction products, is involved in generating the complex.

(iii) Hydrochloric acid, $5 \mathrm{M}$ (method C). Same as method B, except that $5 \mathrm{M}$ hydrochloric acid were used instead of $10 \mathrm{M}$ hydrochloric acid. The peak absorbance for solution containing iron was $351 \mathrm{~nm}$. We have used $10 \mu \mathrm{g}$ iron for hydrochloric acid to visualize the absorbance peak more easily.

(iv) Ascorbic acid, $100 \mathrm{mM}, 5 \mathrm{mM}$ BPS, and $100 \mathrm{mM}$ citric acid (method 
Table 1. Iron Concentrations Measured by Each Method in Different Samples

\begin{tabular}{|c|c|c|c|c|}
\hline Methods & $5 \mu \mathrm{g} / \mathrm{mL}$ & $3 \mu \mathrm{g} / \mathrm{mL}$ & $\begin{array}{c}\text { Labeled THP-1 Cells } \\
\text { (pg/cell) }\end{array}$ & $\begin{array}{c}\text { Iron Recovery } \\
(\mu \mathrm{g})\end{array}$ \\
\hline Hydrochloric Acid Plus Ferrocyanide & $\begin{array}{c}5.034 \pm 0.005 \\
(n=3)\end{array}$ & $\begin{array}{c}2.321 \pm 0.099^{*} \\
(n=3)\end{array}$ & $\begin{array}{l}6.832 \pm 0.677^{*} \\
(1.366 \mu \mathrm{g} / \mathrm{mL})\end{array}$ & $\begin{array}{c}4.967 \pm 0.113 \\
(n=3)\end{array}$ \\
\hline $10 \mathrm{M}$ Hydrochloric Acid & $\begin{array}{c}5.086 \pm 0.006 \\
(n=3)\end{array}$ & $\begin{array}{c}2.228 \pm 0.084^{*} \\
(n=3)\end{array}$ & $\begin{array}{l}3.483 \pm 0.188^{*} \\
(0.697 \mu \mathrm{g} / \mathrm{mL})\end{array}$ & $\begin{array}{c}4.295 \pm 0.198^{*} \\
(n=3)\end{array}$ \\
\hline $5 \mathrm{M}$ Hydrochloric Acid & $\begin{aligned} 5.038 & \pm 0.049 \\
(n & =3)\end{aligned}$ & $\begin{array}{c}3.014 \pm 0.007 \\
(n=3)\end{array}$ & $\begin{array}{l}8.527 \pm 0.156 \\
(1.705 \mu \mathrm{g} / \mathrm{mL})\end{array}$ & $\begin{aligned} 5.210 & \pm 0.364 \\
(n & =3)\end{aligned}$ \\
\hline
\end{tabular}

D). In this method, solutions containing $5 \mu \mathrm{g}$ iron were incubated at $110^{\circ} \mathrm{C}$ overnight (no cap on tubes). After evaporation of the liquid, $1 \mathrm{~mL}$ citric acid (100 mM, pH 2.0) was added to all the tubes and incubated at $60^{\circ} \mathrm{C}$ for $4 \mathrm{~h}$. Tubes were capped to prevent the acid evaporation. After incubation, $0.5 \mathrm{~mL}$ solutions plus $0.5 \mathrm{~mL}$ citric acid were transferred to $1.5-\mathrm{mL}$ cuvettes. Then, $100 \mu \mathrm{L}$ BPS $(5 \mathrm{mM})$ and $50 \mu \mathrm{L}$ freshly prepared ascorbic acid (100 $\mathrm{mM})$ were added to the solution. After $45 \mathrm{~min}$ of incubation at room temperature in dark, the absorbance was measured. Absorption profile of 200-800 nm wavelengths was plotted to determine the peak absorbance wavelength. The peak absorbance for solution containing iron was $535 \mathrm{~nm}$. Citric acid was used to dissolve the cells and iron. Since the core of ferumoxides consists of magnetite $\left(\gamma \mathrm{Fe}_{2} \mathrm{O}_{3}\right)$ with dextran coating, in acidic $\mathrm{pH}$ and/or presence of chelates, iron core will be dissolved and free $\mathrm{Fe}$ (III) will be released into the solution. Bathophenanthroline disulfonic acid forms color with reduced iron $[\mathrm{Fe}(\mathrm{II})]$ that can be measured using a spectrometer at $535 \mathrm{~nm}$ absorbance wavelength. Free Fe(III) can be reduced to $\mathrm{Fe}(\mathrm{II})$ by adding ascorbate.

\section{Generation of Calibration Lines}

Tubes containing from zero to $10 \mu \mathrm{g}$ iron were prepared for each method as just described. After dissolving the iron and adding all the necessary chemical agents, absorbance was measured based on the determined peak absorbance wavelengths of dissolved iron (determined in previous experiment procedures) in each solution. The following absorbance wavelengths were used for different methods: $700 \mathrm{~nm}$ for method A, $351 \mathrm{~nm}$ for methods B and C, and $535 \mathrm{~nm}$ for method D.

\section{Using Known Amount of Ferumoxides}

Since calibration line of all the methods showed a correlation coefficient of $<0.99$ (see Results and Discussion section), we tested the validity of each method to measure iron in samples containing the known amount of iron. Solutions containing either 3 or $5 \mu \mathrm{g} / \mathrm{mL}$ iron were incubated at $110^{\circ} \mathrm{C}$ overnight to dry. For each method to be tested, samples were prepared in triplicate. Iron was dissolved and measured using the procedures described in methods A-D.

\section{Using Iron-Labeled Cells}

Cell labeling. Cells were labeled with a ferumoxides-protamine sulfate complex (FE-PRO). Commercially available ferumoxides suspension (Feridex IV) contains particles approximately $80-150 \mathrm{~nm}$ in size and has a total iron concentration of $11.2 \mathrm{mg} / \mathrm{mL}(11.2 \mu \mathrm{g} / \mu \mathrm{L})$. Protamine sulfate supplied at $10 \mathrm{mg} / \mathrm{mL}$ was prepared at the time of use as a fresh stock solution of $1 \mathrm{mg} / \mathrm{mL}$ in distilled water. Ferumoxides at a concentration of $100 \mu \mathrm{g} / \mathrm{mL}$ was put in a tube containing serum-free RPMI 1640 medium supplemented with minimum essential medium (MEM), nonessential amino acid, and sodium pyruvate. Protamine sulfate was then added to the solution at a concentration of $4.5 \mu \mathrm{g} / \mathrm{mL}$. The solution containing ferumoxides and protamine sulfate was intermittently mixed for 30 $\mathrm{s}$ up to $1 \mathrm{~min}$. Monocytic THP-1 tumor cells were resuspended in $10 \mathrm{~mL} \mathrm{FE}$ PRO complex at the concentration of $4 \times 10^{6}$ cells $/ \mathrm{mL}$. Flasks were incubated for $2 \mathrm{~h}$ at $37^{\circ} \mathrm{C}$ in $5 \% \mathrm{CO}_{2}$ humidified atmosphere after which equal volumes of complete THP-1 growth media [RPMI supplemented with $10 \%$ fetal bovine serum (FBS; HyClone, Logan, UT, USA)] were added to the cells with final concentrations of ferumoxides and protamine sulfate at $50 \mu \mathrm{g} / \mathrm{mL}$ and $2.25 \mu \mathrm{g} / \mathrm{mL}$, respectively. Cell suspension was then incubated overnight $\left(37^{\circ} \mathrm{C}, 5 \% \mathrm{CO}_{2}\right.$ humidified atmosphere). After the overnight incubation with FE-PRO complex, labeled cells were washed three times with PBS to eliminate nonincorporated extracellular iron (3).

Measuring intracellular iron. For each method, three $1.5-\mathrm{mL}$ microcentrifuge tubes were filled with total of $2 \times 10^{5}$ cells per tube. Cells were then centrifuged at 3000 RPM for 5 min. After discarding the supernatant, cell pellets were incubated at $110^{\circ} \mathrm{C}$ overnight (no cap on tubes). The iron was dissolved and measured using the procedures described in methods A-D. The average absorbance values for each sample (three tubes for each sample) were divided by the number of cells to determine the average iron concentration per cell. Iron concentration was determined by normalizing the obtained absorbance values with a previously prepared calibration line.

Iron recovery from cells. To determine the validity and accuracy of each method to recover the intracellular iron, $2 \times 10^{5}$ THP- 1 cells in each well of a 96-well plate were incubated with $50 \mu \mathrm{L}$ FE-PRO complex (containing 5 
$\mu \mathrm{g}$ iron) for $2 \mathrm{~h}$ after which an equal volume $(50 \mu \mathrm{L})$ of complete THP-1 growth media was added to each well and further incubated overnight. After the overnight labeling and drying of labeled cells (without washing), acids were added to the cells based on methods A-D. After dissolving the cells and iron for $4 \mathrm{~h}$ at $60^{\circ} \mathrm{C}$ in respective acids, iron concentration in each well (three wells for each method) was determined according to the four methods.

Statistical analysis. Analysis of variance (ANOVA) was used to determine the significant differences in measuring iron among the methods. A $P$-value of 0.05 was considered significant difference.

\section{RESULTS AND DISCUSSION}

\section{Spectra of Hydrochloric Acid Plus Ferrocyanide With or Without Iron}

A mixture of $5 \mathrm{M}$ hydrochloric acid and 5\% ferrocyanide without iron (Figure 1A, top panel) showed a typical absorbance profile of the solution alone that extended from 200 to $400 \mathrm{~nm}$. However, there was no absorbance observed beyond $400 \mathrm{~nm}$. On the other hand, the same solution mixed with $5 \mu \mathrm{g} / \mathrm{mL}$ iron (Figure $1 \mathrm{~A}$, bottom panel) produced a Prussian blue color, and the absorbance profile showed another peak absorbance at $700 \mathrm{~nm}$ that was not observed in the profile generated from the solution without iron. Based on this absorbance profile (700 $\mathrm{nm}$ wavelength) we created calibration line (Figure 1B) that was used for measuring iron concentration in samples with the known iron concentration and in the iron-labeled cells (Table 1). The combination of $5 \mathrm{M}$ hydrochloric acid plus ferrocyanide was accurate in determining the iron concentration when the concentration of iron in known samples was equal to or above $5 \mu \mathrm{g} / \mathrm{mL}$. However, when the concentration of iron was $3 \mu \mathrm{g} / \mathrm{mL}$, the calculated iron concentrations were not accurate (Table 1). Prussian blue color development and changes in optical density become stable 35 min after the addition of ferrocyanide.
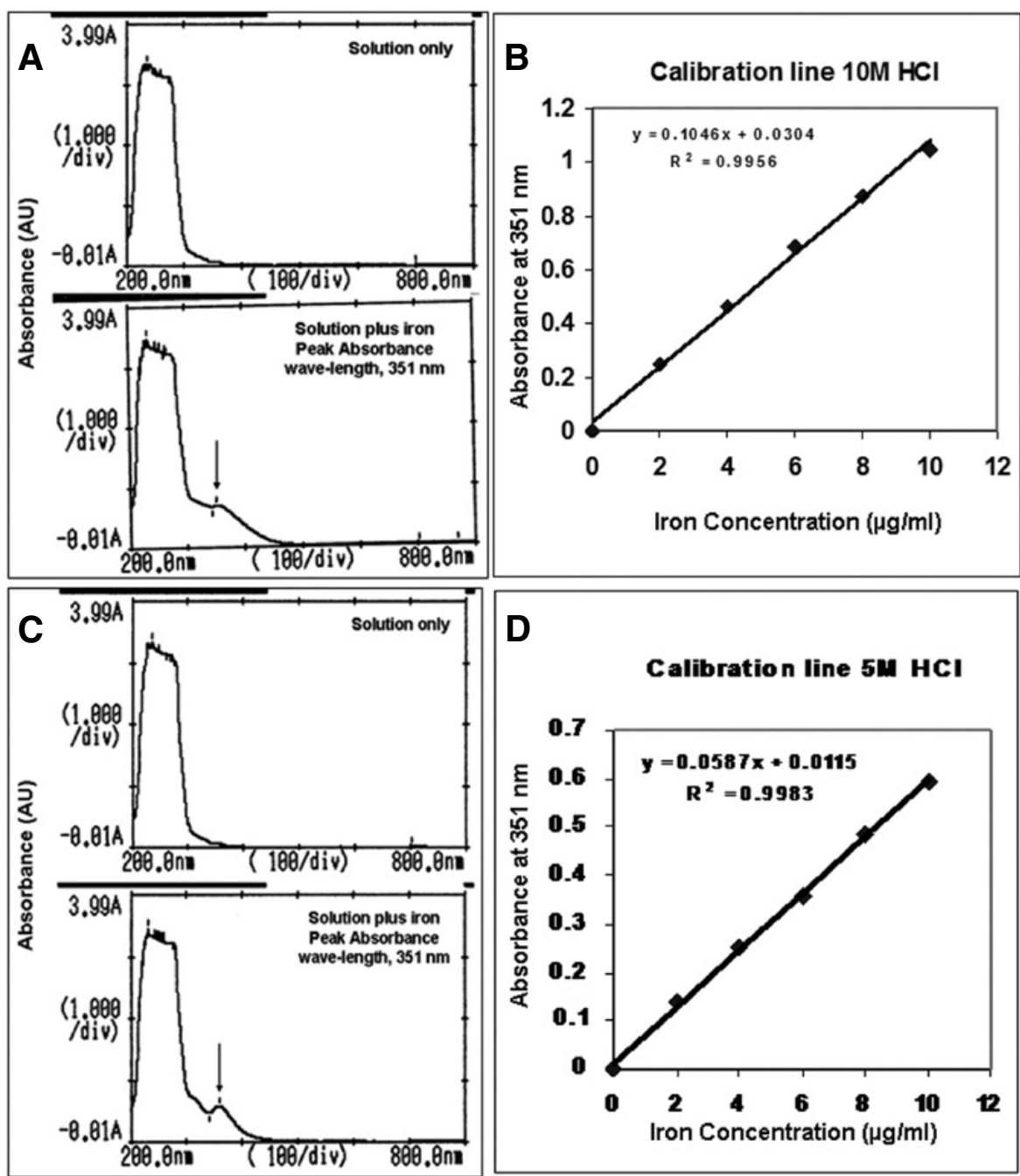

Figure 2. Peak absorbance values and calibration line for 10 and $5 \mathrm{M}$ hydrochloric acid methods. (A) Peak absorbance values for $10 \mathrm{M}$ hydrochloric acid without iron (top panel) and with $10 \mu \mathrm{g}$ iron (bottom panel). (B) The calibration line for $10 \mathrm{M}$ hydrochloric acid method generated by using iron in concentration ranging from 0 to $10 \mu \mathrm{g} / \mathrm{mL}$. (C) Peak absorbance values for $5 \mathrm{M}$ hydrochloric acid without iron (top panel) and with $10 \mu \mathrm{g}$ iron (bottom panel). (D) The calibration line for $5 \mathrm{M}$ hydrochloric acid method generated by using iron in concentration ranging from 0 to $10 \mu \mathrm{g} / \mathrm{mL}$.

\section{Spectra of Hydrochloric Acid With or Without Iron}

Both, $10 \mathrm{M} \mathrm{HCl}$ alone (Figure 2A, top panel) and $5 \mathrm{M} \mathrm{HCl}$ alone (Figure $2 \mathrm{C}$, top panel) showed a typical absorbance profile that extended from 200 to $320 \mathrm{~nm}$. However, no absorbance was observed beyond $320 \mathrm{~nm}$. On the other hand, both 5 and $10 \mathrm{M} \mathrm{HCl}$ with iron showed another peak at $351 \mathrm{~nm}$ that was not observed in profiles generated from the solutions without iron. Based on the absorbance profile (351 nm wavelength), we created calibration lines that were used for measuring the concentration of iron in the samples with known iron concentration and in the iron-labeled cells. Calibration lines generated with 5 and $10 \mathrm{M} \mathrm{HCl}$ were consistent in showing significant correlation coefficient.

\section{Spectra of Ascorbic Acid, BPS, and Citric Acid With or Without Iron}

Absorbance profile observed in solution without iron containing citric acid, ascorbic acid, and BPS extended from 280 to $400 \mathrm{~nm}$, with no absorbance observed beyond the $400 \mathrm{~nm}$ (Figure 3A, top panel). On the other hand, the solution with iron produced 


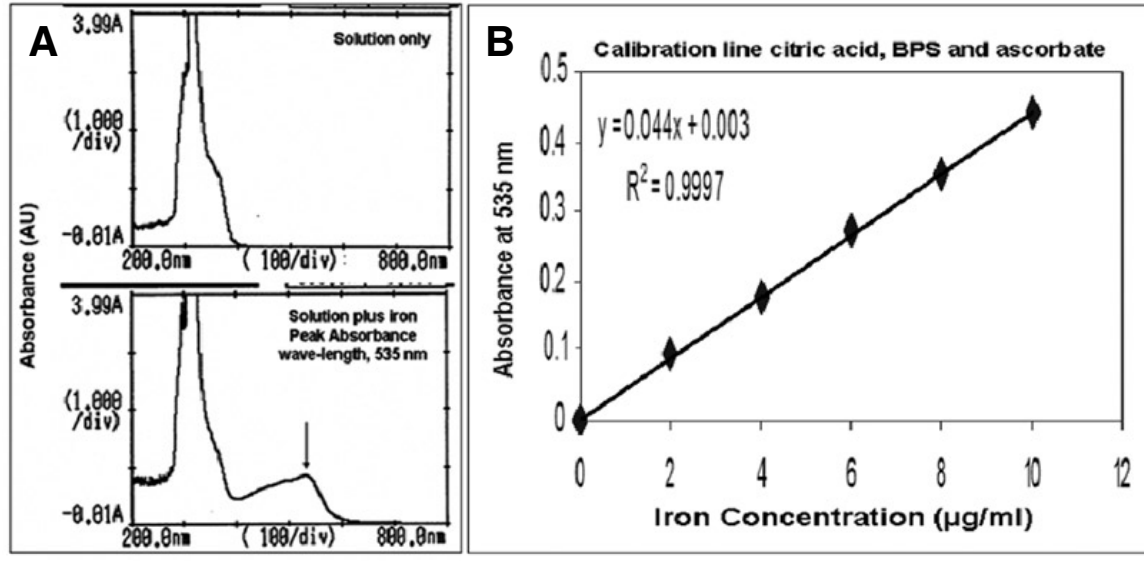

Figure 3. Peak absorbance values and calibration line for $100 \mathrm{mM}$ ascorbic acid, $5 \mathrm{mM}$ bathophenanthroline sulphonate (BPS), and $100 \mathrm{mM}$ citric acid method. (A) Peak absorbance values for $100 \mathrm{mM}$ ascorbic acid, $5 \mathrm{mM}$ BPS, and $100 \mathrm{mM}$ citric acid without iron (top panel) and with $5 \mu \mathrm{g}$ iron (bottom panel). (B) The calibration line for $100 \mathrm{mM}$ ascorbic acid, $5 \mathrm{mM}$ BPS, and $100 \mathrm{mM}$ citric acid method generated by using iron in concentration ranging from 0 to $10 \mu \mathrm{g} / \mathrm{mL}$.

color that ranged from deep pink to maroon and it gave an absorbance peak at $535 \mathrm{~nm}$ (Figure 3A, bottom panel). The color change was quite rapid and there were no differences between absorbance values measured at 10 and $45 \mathrm{~min}$. The correlation coefficient for calibration lines was $>0.99$ (Figure 3B).

\section{Calibration Lines}

Based on the absorbance peak wavelengths determined by the methods described, absorbance values of samples containing known concentrations of iron $(0-10 \mu \mathrm{g}$ iron per milliliter) were measured to generate the calibration lines (Figure 1B, Figure 2, B and D, and Figure 3B). All the methods showed a significant correlation between the concentration of iron in the solution and absorbance values $\left(r^{2}>0.99\right)$.

\section{Measurement of Iron in the Samples With Known Iron Concentration and in Iron-Labeled Cells}

To conclude whether these methods can determine the concentration of iron in samples with the known, high or low concentration of iron, $1 \mathrm{~mL}$ solution containing either 3 or $5 \mu \mathrm{g} / \mathrm{mL}$ of iron was incubated at $110^{\circ} \mathrm{C}$ overnight, to dry. Dried samples were then dissolved using the respective acids, and iron was measured as described in the Materials and Methods section. Table 1 shows the concentration of iron that was determined by different methods for the corresponding known amount of iron in the solution and in iron-labeled cells. Both $5 \mathrm{M}$ hydrochloric acid and citric acid methods showed similar iron concentration in labeled cells and showed consistent containing either 5 or $3 \mu \mathrm{g} / \mathrm{mL}$ iron. However, the $10 \mathrm{M}$ hydrochloric acid and $5 \mathrm{M}$ hydrochloric acid plus ferrocyanide methods significantly in known samples containing $3 \mu \mathrm{g}$ iron per milliliter and in labeled cells. In contrast to the results obtained with $5 \mathrm{M}$ hydrochloric acid, $10 \mathrm{M}$ hydrochloric acid underestimated iron concentration in the cells. Similar results were also seen in samples with the known concentration of iron. However, when the iron concentration reached $5 \mu \mathrm{g} / \mathrm{mL}$, all the methods showed almost identical values that were in agreement with the values obtained from samples containing known amounts of iron. The cause of underestimation of iron measurement with $10 \mathrm{M}$ hydrochloride acid for samples with lower concentrations of iron is not known, but it is possible that the excessive free chloride in solution might have decreased the iron concentration in solutions underestimated the iron concentration absorbance of iron. Ferrocyanide reaction kinetics may also be related to the amount of iron in the solution, and proper reaction equilibrium with iron was not achieved at the low iron concentrations.

\section{Recovery Extra and Intracellular Iron After Cell Labeling}

To determine the efficiency of each method to recover intracellular iron and the effect of cell matrix on iron measurements, FE-PRO complexes containing $5 \mu \mathrm{g}$ iron were added to wells containing $2 \times 10^{5}$ THP- 1 cells. Cells were labeled overnight and dried at $110^{\circ} \mathrm{C}$ (without washing), and iron concentration in each well (three wells for each method) was determined according to the described methods. Table 1 also shows the recovered iron by each method. Both 5 and $5 \mathrm{M}$ hydrochloric acid plus ferrocyanide showed excellent recovery of iron added to cell cultures, and cellular debris generated after lysing the cells did not have any significant effect on measured iron concentration. On the other hand, both $10 \mathrm{M}$ hydrochloric acid and the method using citric acid and ascorbic acid showed significantly lower amount of measured iron. As seen in other experiments, $10 \mathrm{M}$ hydrochloric acid, again, underestimated the recovered iron. Based on our findings, it can be concluded that $10 \mathrm{M}$ hydrochloric acid is not a suitable method for measuring iron concentration. To accurately measure with this method, there should be a minimum $3 \mu \mathrm{g} / \mathrm{mL}$ iron in the sample.

\section{Limitation of the Methods}

We have not compared our methods with other techniques for determining iron concentrations, such as ICPMS, ICP-OES, or atomic absorption spectrophotometer (AAS). However, comparing the measured iron concentrations in samples containing a known amount of iron or a known number of labeled cells validates the correctness of our investigations to compare iron measuring capacity of four different $\mathrm{UV} /$ spectroscopic methods. 


\section{ACKNOWLEDGMENTS}

This work is supported partially by NIH grant no. R01-EB002450.

\section{COMPETING INTERESTS STATEMENT}

The authors declare no competing interests.

\section{REFERENCES}

1. Rad, A.M., A.S. Arbab, A.S. Iskander, Q. Jiang, and H. Soltanian-Zadeh. 2007. Quantification of superparamagnetic iron oxide (SPIO)-labeled cells using MRI. J. Magn. Reson. Imaging 26:366-374.

2. Anderson, S.A., J. Glod, A.S. Arbab, M. Noel, P. Ashari, H.A. Fine, and J.A. Frank. 2005. Noninvasive MR imaging of magnetically labeled stem cells to directly identify neovasculature in a glioma model. Blood 105:420-425.

3. Arbab, A.S., G.T. Yocum, H. Kalish, E.K. Jordan, S.A. Anderson, A.Y. Khakoo, E.J. Read, and J.A. Frank. 2004. Efficient magnetic cell labeling with protamine sulfate complexed to ferumoxides for cellular MRI. Blood 104:1217-1223.

4. Daldrup-Link, H.E., M. Rudelius, G. Piontek, S. Metz, R. Brauer, G. Debus, C. Corot, J. Schlegel, et al. 2005. Migration of iron oxide-labeled human hematopoietic progenitor cells in a mouse model: in vivo monitoring with 1.5-T MR imaging equipment. Radiology 234:197-205.

5. Frank, J.A., H. Zywicke, E.K. Jordan, J. Mitchell, B.K. Lewis, B. Miller, L.H. Bryant, Jr., and J.W. Bulte. 2002. Magnetic intracellular labeling of mammalian cells by combining (FDA-approved) superparamagnetic iron oxide MR contrast agents and commonly used transfection agents. Acad. Radiol. 9(Suppl 2):S484-S487.

6. Frank, J.A., B.R. Miller, A.S. Arbab, H.A. Zywicke, E.K. Jordan, B.K. Lewis, L.H. Bryant, Jr., and J.W. Bulte. 2003. Clinically applicable labeling of mammalian and stem cells by combining superparamagnetic iron oxides and transfection agents. Radiology 228:480-487.

7. Arbab, A.S., L.A. Bashaw, B.R. Miller, E.K. Jordan, B.K. Lewis, H. Kalish, and J.A. Frank. 2003. Characterization of biophysical and metabolic properties of cells labeled with superparamagnetic iron oxide nanoparticles and transfection agent for cellular MR imaging. Radiology 229:838-846.

8. Yocum, G.T., L.B. Wilson, P. Ashari, E.K. Jordan, J.A. Frank, and A.S. Arbab. 2005. Effect of human stem cells labeled with ferumoxides-poly-L-lysine on hematologic and biochemical measurements in rats. Radiology 235:547-552.

9. Sundstrom, J.B., H. Mao, R. Santoianni, F. Villinger, D.M. Little, T.T. Huynh, A.E.
Mayne, E. Hao, et al. 2004. Magnetic resonance imaging of activated proliferating rhesus macaque $\mathrm{T}$ cells labeled with superparamagnetic monocrystalline iron oxide nanoparticles. J. Acquir. Immune Defic. Syndr. 35:9-21.

10. Heyn, C., C.V. Bowen, B.K. Rutt, and P.J. Foster. 2005. Detection threshold of single SPIO-labeled cells with FIESTA. Magn. Reson. Med. 53:312-320.

11. Kettering, M., J. Winter, M. Zeisberger, C. Alexiou, S. Bremer-Streck, C. Bergemann, W.A. Kaiser, and I. Hilger. 2006. Magnetically based enhancement of nanoparticle uptake in tumor cells: combination of magnetically induced cell labeling and magnetic heating. Rofo. 178:1255-1260.

12. Wilhelm, C., C. Billotey, J. Roger, J.N. Pons, J.C. Bacri, and F. Gazeau. 2003. Intracellular uptake of anionic superparamagnetic nanoparticles as a function of their surface coating. Biomaterials 24:1001-1011.

13. Riviere, C., F.P. Boudghene, F. Gazeau, J. Roger, J.N. Pons, J.P. Laissy, E. Allaire, J.B. Michel, et al. 2005. Iron oxide nanoparticle-labeled rat smooth muscle cells: cardiac MR imaging for cell graft monitoring and quantitation. Radiology 235:959-967.

14. Arbab, A.S., L.B. Wilson, P. Ashari, E.K. Jordan, B.K. Lewis, and J.A. Frank. 2005. A model of lysosomal metabolism of dextran coated superparamagnetic iron oxide (SPIO) nanoparticles: implications for cellular magnetic resonance imaging. NMR Biomed. 18:383-389.

15. Daldrup-Link, H.E., M. Rudelius, R.A. Oostendorp, M. Settles, G. Piontek, S. Metz, H. Rosenbrock, U. Keller, et al. 2003. Targeting of hematopoietic progenitor cells with MR contrast agents. Radiology 228:760767.

16. Ju, S., G. Teng, Y. Zhang, M. Ma, F. Chen, and Y. Ni. 2006. In vitro labeling and MRI of mesenchymal stem cells from human umbilical cord blood. Magn. Reson. Imaging 24:611-617.

Received 2 April 2007; accepted 6 September 2007.

Address correspondence to Ali S Arbab, Department of Radiology, Henry Ford Hospital, 1 Ford Place, 2F, Box-82, Detroit, MI 48188, USA.e-mail: saali@rad.hfh.edu

To purchase reprints of this article, contact: Reprints@BioTechniques.com 